\title{
Case-control study of prostatic cancer in employees of the United Kingdom Atomic Energy Authority
}

\author{
Cleone Rooney, Valerie Beral, Noreen Maconochie, Patricia Fraser, Graham Davies
}

\begin{abstract}
Objective-To investigate the relation between risk of prostatic cancer and occupational exposures, especially to radionuclides, in employees of the United Kingdom Atomic Energy Authority.

Design-Case-control study of men with prostatic cancer and matched controls. Information about sociodemographic factors and exposures to radionuclides and other substances was abstracted and classified for each subject from United Kingdom Atomic Energy Authority records without knowledge of who had cancer.

Subjects-136 men with prostatic cancer diagnosed between 1946 and 1986 and 404 matched controls, all employees of United Kingdom Atomic Energy Authority.
\end{abstract}

Main outcome measures-Documented or possible contamination with specific radionuclides.

Results-Risk of prostatic cancer was significantly increased in men who were internally contaminated with or who worked in environments potentially contaminated by tritium, chromium-51, iron-59, cobalt-60, or zinc- 65 . Internal contamination with at least one of the five radionuclides was detected in 14 men with prostatic cancer $(10 \%)$ and 12 controls $(3 \%)$ (relative risk $5.32(95 \%$ confidence interval 1.87 to 17.24). Altogether 28 men with prostatic cancer $(21 \%)$ and 46 controls $(11 \%)$ worked in environments potentially contaminated by at least one of the five radionuclides (relative risk $2.36(1.26$ to 4.43$)$ ); about two thirds worked at heavy water reactors (19 men with prostatic cancer and 32 controls (relative risk $2 \cdot 13(1.00$ to $4 \cdot 52)$ ). Relative risk of prostatic cancer increased with increasing duration of work in places potentially contaminated by these radionuclides and with increasing level of probable contamination. Prostatic cancer was not associated with exposure to plutonium, uranium, cadmium, boron, beryllium, or organic or inorganic chemicals.

Conclusions-Risk of prostatic cancer risk was increased in United Kingdom Atomic Energy Authority workers who were occupationally exposed to tritium, ${ }^{51} \mathrm{Cr},{ }^{59} \mathrm{Fe},{ }^{\infty 0} \mathrm{Co}$, or ${ }^{\circ 5} \mathrm{Zn}$. Exposure to these radionuclides was infrequent, and their separate effects could not be evaluated.

\section{Introduction}

In a cohort study of employees of the United Kingdom Atomic Energy Authority, mortality from prostatic cancer was found to be increased in workers who had accumulated comparatively high exposures from external sources of ionising radiation and who had undergone investigation for possible internal contamination by tritium and unspecified radionuclides. ${ }^{1}$ No information was available about the radionuclides included in the unspecified category, on whether people who had been investigated for possible contamination by radionuclides actually had evidence of internal contamination, or on place of work. The case-control study reported here was set up to obtain detailed information on contamination by specific radionuclides, on other occupational exposures, on place of work, and on sociodemographic factors in United Kingdom Atomic Energy Authority employees with prostatic cancer and matched controls. The original report included 28 men aged under 75 who died of prostatic cancer in 1946-79, ${ }^{1}$ and this casecontrol study includes 136 men who died of prostatic cancer or in whom it was diagnosed in 1946-86.

\section{Subjects and methods}

SUBJECTS

During systematic follow up of the United Kingdom Atomic Energy authority's workforce ${ }^{2}$ the NHS central register listed 136 men who had died from prostatic cancer or who were registered as having it before the end of 1986. We obtained evidence of histological confirmation of the diagnosis for $95(70 \%)$ from cancer registrations or hospital records. For each case of prostatic cancer we tried to select three controls from the workforce (after exclusion of cases) by sampling with replacement. The controls were matched for year of starting work with the authority (to within one year except for nine cases described below), age at starting work (to within two years except for nine cases described below), last place of work, ever having been monitored for exposure to ionising radiation, and survival for at least as long as the interval between the start of employment and the date of cancer registration or death of the corresponding case. For 127 of the cases three controls were randomly selected from a pool of potential controls who matched exactly on all five criteria, although two controls were subsequently excluded when it was found that they had not survived as long as the corresponding case. For nine cases no exactly matching control could be identified so two of the matching criteria (firstly the year and secondly the age of starting work) were relaxed at one year intervals to a maximum of five years each. Despite these relaxations one case could be matched to only one control. The final study population thus consisted of 136 cases matched to 404 controls comprised of 372 individuals, of whom 28 were matched to more than one case.

Some information about each subject, including the dates of entering and leaving employment with the United Kingdom Atomic Energy Authority and data on annual exposures to external sources of radiation, had already been collected and validated as part of the original cohort study. ${ }^{2}$ One of us (CR) abstracted further data from occupational health, personnel, and radiation records held by the United Kingdom Atomic Energy Authority without knowing whether subjects were cases or controls. The information included radionuclide exposures, place of work, type of work done, marital status, number of children, history of sexually transmitted diseases, prior employment in the armed forces, and details of diagnostic $x$ rays performed at atomic energy authority establishments. Data from different sources were cross checked and discrepancies were resolved when necessary, although the data were generally consistent.

INTERNAL CONTAMINATION BY RADIONUCLIDES

Although monitoring for internal contamination has been legally required only since 1986 , some employees

Dr Beral. 
of the United Kingdom Atomic Energy Authority have been investigated for possible internal contamination since the late 1940s if, in the opinion of the health physicist concerned, they were potentially exposed (United Kingdom Atomic Energy Authority personal communication). Early analytical methods tended to be non-specific assays for radioactivity in the urinesuch as for gross $\alpha$, gross $\beta$ or gross $\gamma$ activitywithout necessarily identifying the specific radionuclide giving rise to the activity. After the late $1950 \mathrm{~s}$ specific bioassays were performed in selected individuals for all isotopes of plutonium and uranium and for tritium

Whole body monitoring, which can detect a spectrum of individual radionuclides in the body, has been used since the 1960s at all establishments for workers who have had an unexpected result on bioassay or were involved in an incident in which exposure was thought likely to have occurred. At Winfrith and Dounreay whole body monitoring was undertaken routinely after 1960 for certain workers, and results were notified only if contamination was detected. Copies of all original records of investigations for internal contamination, including the dates and results of each investigation, were requested for all the subjects in the study.

POTENTIAL EXPOSURE TO RADIONUCLIDES AND OTHER SUBSTANCES AT WORK

A list of 125 buildings or work areas where exposure to any of 15 specific radionuclides might have occurred was compiled in consultation with health physicists and other experienced staff of the United Kingdom Atomic Energy Authority. Each building was classified into one of four levels of potential exposure for each radionuclide (none, possible, probable but relatively low level, and probable and relatively high level). Health physicists with detailed knowledge of the authority's activities and radiation protection practices over several decades reviewed each subject's work and exposure history. They recorded whether the subject had ever worked in each of the 125 workplaces and, if so, the calendar years and type of work done. They also recorded each subject's potential exposure to other possible hazards (six metals, three groups of chemicals, three physical agents, and seven other types of radiation). The level of exposure to each was classified as none (or unlikely), probable but relatively low level, and probable and relatively high level. If exposure was probable, the calendar years and frequency of exposure were also recorded. The health physicists made the classifications without knowing who was a case or a control.

\section{STATISTICAL ANALYSIS}

We estimated relative risks for prostatic cancer in relation to exposure to radionuclides and other possible hazards as matched odds ratios by means of conditional maximum likelihood methods. ${ }^{3}$ Exposure information for controls was censored on the date of diagnosis (registration of cancer or certification of death) of the corresponding case. Because the numbers of informative matched sets were small in many of the analyses, we calculated $95 \%$ confidence intervals and $p$ values for relative risks with exact methods based on the binomial distribution. However, when more than two levels of exposure were analysed we calculated relative risks, $95 \%$ confidence intervals, and $\mathrm{p}$ values by means of conditional logistic regression to ensure that the estimated relative risks were consistent for different pairs of exposure levels. Where appropriate, we obtained an approximate $\chi^{2}$ test for trend $(\mathrm{df}=1)$ across increasing levels of exposure by fitting a conditional logistic regression model after assigning a score to each level of exposure and treating this as a continuous variable in the analysis. All analyses were done with EGRET,${ }^{4}$ and all $p$ values quoted are two sided.

\section{Results}

The 136 men with prostatic cancer included 74 for whom prostatic cancer was the underlying cause of death (mean (SD) age at death $69.7(9.54)$ years), 26 for whom it was an associated cause of death in that it was mentioned on the death certificate but was not specified as the underlying cause of death (age at death 76.3 $(6.56)$ years), and 36 who were registered with prostatic cancer (age at registration $70 \cdot 1(7 \cdot 8)$ years). Altogether 31 of the men were aged less than 65,50 were aged 65 74 , and 55 were 75 or older. The average time between first employment by the United Kingdom Atomic Energy Authority and the date of registration or death from prostatic cancer was $22.8(7 \cdot 78)$ years. The United Kingdom Atomic Energy Authority establishments where the men last worked were Winfrith (29 men), Harwell (77), Dounreay (8), and Risley, Culham, or the London Office (22).

Table I shows other characteristics of the cases and those of the matched controls. The average age and calendar year of first employment by the authority were virtually identical for the cases and controls, as was the average length of employment with the authority and the distribution of social classes as defined by the final job with the authority. Military service was mentioned in the records of more than half of the men with prostatic cancer and a similar proportion of controls. The occupational health records contained little information about history of sexually transmitted disease or family history of prostatic cancer but did give details of marital status for $90 \%$ of cases and $91 \%$ of controls: most men had been married and had children, and the cases and controls were similar in this respect. Diagnostic $x$ rays had been taken at an authority establishment for $119(88 \%)$ cases and $353(87 \%)$ controls for whom information was available, and there was no difference between the cases and controls in their exposure to diagnostic $x$ rays which might have irradiated the prostate (table I).

The men with prostatic cancer and the controls were matched exactly according to whether they had a record of being monitored for exposure to any source of

TABLE I-Characteristics of men with prostatic cancer (cases) and their matched controls who were employees of United Kingdom Atomic Energy Authority. Values are numbers (percentages) unless stated otherwise

\begin{tabular}{ccc}
\hline & Cases \\
$(n=136)$ & $\begin{array}{c}\text { Controls } \\
(n=404)\end{array}$ \\
\hline
\end{tabular}

Variables for which cases and controls were individually matched

Mean (SD) age at first employment by authority $48.7(11 \cdot 1) \quad 48 \cdot 3(11 \cdot 0)$ Mean $(\mathrm{S})$
(years)

(years)

When first employed by authority:

Before 1950

$1950-9$

After 1959

Ever monitored for exposure to ionising radiation ${ }^{\star}$

Other variables

Mean (SD) years of employment by authority

Social class:

III (non-manual)

III (manual)

IV and V

Military servicet

Demographic variables:

Ever married

Ever had children

Mean (SD) No of children

Diagnostic $x$ rays taken by authority: $†$

Of pelvis, hip, or sacrum

Of abdomen or lumbar spine

Of lower limb

$\begin{array}{rr}29(21) & 81(20) \\ 72(53) & 211(52) \\ 35(26) & 112(28) \\ 88(65) & 260(64)\end{array}$

$11.8(8 \cdot 62) \quad 12 \cdot 8(9 \cdot 23)$

$37(27) \quad 105(26)$

$13(10) \quad 43(11)$

$25(18) \quad 62(15)$

$\begin{array}{ll}61(45) & 194(48) \\ 72(62) & 208(61)\end{array}$

$115(94) \quad 345(94)$

$98(87) \quad 258(82)$

$\begin{array}{ll}2.6(1.68) & 2.4(1.59)\end{array}$

$10(8) \quad 35(10)$

$10(8) \quad 29(8)$

$37(31) \quad 102(29)$

*Controls were matched exactly to cases on this variable, but two cases had only two matched controls and one case had only one matched control. In those for whom the information was available. 
TABLE II-Summary of investigations for internal contamination among men with prostatic cancer and their matched controls employed by the United Kingdom Atomic Energy Authority

\begin{tabular}{|c|c|c|c|c|c|}
\hline \multirow[b]{2}{*}{ Radionuclide } & \multirow{2}{*}{$\begin{array}{l}\text { Year when any } \\
\text { investigation first } \\
\text { recorded in a subject }\end{array}$} & \multirow{2}{*}{$\begin{array}{l}\text { No of subjects with } \\
\text { contamination detected } \\
\text { (No of subjects } \\
\text { with records of } \\
\text { investigations) }\end{array}$} & \multicolumn{3}{|c|}{$\begin{array}{l}\text { No (\%) of subjects with contamination } \\
\text { detected by establishment }\end{array}$} \\
\hline & & & $\begin{array}{l}\text { Winfrith } \\
(\mathrm{n}=115)\end{array}$ & $\begin{array}{l}\text { Harwell } \\
(\mathrm{n}=307)\end{array}$ & $\begin{array}{c}\text { Dounreay } \\
(\mathrm{n}=32)\end{array}$ \\
\hline Uranium-235* & 1948 & $6(12)$ & $4(3)$ & $1(0.3)$ & $1(3)$ \\
\hline Plutonium-239* & 1949 & $22(44)$ & $4(3)$ & $12(4)$ & $6(19)$ \\
\hline Gross $\alpha^{\star}$ & 1953 & $16(24)$ & $1(1)$ & $15(5)$ & 0 \\
\hline Gross $\beta^{\star}$ & 1955 & $22(34)$ & $1(1)$ & $18(6)$ & $3(9)$ \\
\hline Tritium* ${ }^{\star}$ & 1957 & $18(23)$ & $7(6)$ & $10(3)$ & $1(3)$ \\
\hline Natural uranium ${ }^{\star}$ & 1957 & $6(20)$ & $2(2)$ & 0 & $4(13)$ \\
\hline Caesium-137 $\dagger$ & 1961 & $19 \ddagger$ & $14(12)$ & $1(0 \cdot 3)$ & $4(13)$ \\
\hline Gross $\gamma^{\star}$ & 1961 & $2(10)$ & 0 & $2(1)$ & 0 \\
\hline Strontium- $90^{\star} \dagger$ & 1966 & $10 \ddagger$ & $9(8)$ & $1(0.3)$ & 0 \\
\hline Iodine- $131^{\star} \dagger$ & 1968 & $15 \ddagger$ & $11(10)$ & $4(1)$ & 0 \\
\hline Cobalt-60† & 1969 & $15 \ddagger$ & $13(11)$ & $2(1)$ & 0 \\
\hline Caesium-134† & 1969 & $13 \ddagger$ & $13(11)$ & 0 & 0 \\
\hline Zinc-65t & 1969 & $3 \ddagger$ & $2(2)$ & $1(0 \cdot 3)$ & 0 \\
\hline Iron-59t & 1970 & $5 \ddagger$ & $5(4)$ & 0 & 0 \\
\hline Cerium-141† & 1970 & $4 \ddagger$ & $4(3)$ & 0 & 0 \\
\hline Barium-140 $\dagger$ & 1972 & $4 \ddagger$ & $4(3)$ & 0 & 0 \\
\hline
\end{tabular}

Table lists radionuclides most often detected and gross $\alpha, \beta$, and $\gamma$ activity in urine.

Usual method of detection by *urine analysis or twhole body monitoring.

$\ddagger$ Records of negative results (no contamination detected) not available for whole body monitoring.

TABLE III-Risk of prostatic cancer associated with documented internal contamination by specific radionuclides among men with prostatic cancer (cases) and matched controls employed by the United Kingdom Atomic Energy Authority

\begin{tabular}{|c|c|c|c|}
\hline \multirow[b]{2}{*}{ Radionuclide } & \multicolumn{2}{|c|}{$\begin{array}{l}\text { No }(\%) \text { of subjects with } \\
\text { documented internal } \\
\text { contamination }\end{array}$} & \multirow[b]{2}{*}{$\begin{array}{l}\text { Relative risk }(95 \% \\
\text { confidence interval) } \dagger\end{array}$} \\
\hline & $\begin{array}{c}\text { Cases } \\
(n=136)\end{array}$ & $\begin{array}{l}\text { Controls } \\
(n=404)\end{array}$ & \\
\hline Tritium & $12(9)$ & $6(1)$ & $14.26(3.09 \text { to } 133.16)^{\star \star}$ \\
\hline Iron-59 & $4(3)$ & $1(0 \cdot 2)$ & $12.00(1.19 \text { to } 590.99)^{\star}$ \\
\hline Cobalt- 60 & $8(6)$ & $7(2)$ & $4.76(1.23 \text { to } 22.14)^{\star}$ \\
\hline Zinc-65 & $2(1)$ & $1(0 \cdot 2)$ & $6.00(0.31$ to 353.99$)$ \\
\hline Strontium-90 & $4(3)$ & $6(1)$ & $2.00(0.42$ to 8.43$)$ \\
\hline Iodine-131‡ & $5(4)$ & $10(2)$ & $1.50(0.40$ to 4.82$)$ \\
\hline Caesium-134 & $7(5)$ & $6(1)$ & $7.46(1.32 \text { to } 76.67)^{\star}$ \\
\hline Caesium-137 & $9(7)$ & $10(2)$ & $3.57(1.09 \text { to } 12.58)^{\star}$ \\
\hline Barium-140 & $3(2)$ & $1(0 \cdot 2)$ & $9.00(0.72$ to $472 \cdot 46)$ \\
\hline Cerium-141 & $2(1)$ & $2(0.5)$ & $4.37(0.21$ to 275.13$)$ \\
\hline Uranium-235 & 0 & $6(1)$ & $0(0$ to 2.55$)$ \\
\hline Natural uranium & $2(1)$ & $4(1)$ & $1.59(0.13$ to 14.59$)$ \\
\hline Plutonium-239 & $5(4)$ & $17(4)$ & $0.88(0.24$ to 2.58$)$ \\
\hline
\end{tabular}

Radionuclides detected infrequently: antimony-124 (1 control), cerium-144 (1 control), chromium-51 (1 control). cobalt-58 (1 case), lead $203 \ddagger(1$ control), lead-212 ( 1 control), manganese- 54 ( 1 case, 2 controls), mercury203 ( 1 control), proactinium ( 1 control), radium-226 (1 case, 2 controls), sodium-22 ( 1 control), sodium-24 $(1$ case, 3 controls), thorium ( 1 control), uranium-233 (1 case, 2 controls), xenon-133 (1 case), zirconium-95 (3

${ }^{\star} \mathrm{p}<0.05,{ }^{\star \star} \mathrm{p}<0.0$

$\nmid$ Relative to no documented internal contamination with each radionuclide, calculated with informative matched sets only.

¥Includes volunteers in physiological studies of ${ }^{131} \mathrm{I}$ ( 1 case and 3 controls) and ${ }^{203} \mathrm{~Pb}$ ( 1 control $)$.

TABLE IV-Risk of prostatic cancer associated with potential contamination of the workplace by 15 specific radionuclides among men with prostatic cancer (cases) and matched controls employed by the United Kingdom Atomic Energy Authority

\begin{tabular}{|c|c|c|c|c|c|c|}
\hline \multirow[b]{2}{*}{ Radionuclide } & \multicolumn{4}{|c|}{ Relative risk by level of potential contamination $\dagger$} & \multicolumn{2}{|c|}{$\begin{array}{l}\text { No (\%) of subjects exposed } \\
\text { to probable contamination } \\
\text { (high or low level) }\end{array}$} \\
\hline & Possible & $\begin{array}{c}\text { Probable } \\
\text { but low } \\
\text { level }\end{array}$ & $\begin{array}{l}\text { Probable } \\
\text { but high } \\
\text { level }\end{array}$ & $\begin{array}{c}\chi^{2} \\
\text { For trend }\end{array}$ & $\begin{array}{c}\text { Cases } \\
(n=136)\end{array}$ & $\begin{array}{l}\text { Controls } \\
(n=404)\end{array}$ \\
\hline Tritium & 1.54 & 0.79 & $2 \cdot 45^{\star}$ & $5 \cdot 85^{\star}$ & $19(14)$ & $32(8)$ \\
\hline Chromium-51 & 1.32 & 1.91 & $5 \cdot 70^{\star \star}$ & $10 \cdot 23^{\star \star}$ & $26(19)$ & $42(10)$ \\
\hline Iron-59 & 0.53 & 1.88 & $5 \cdot 90^{\star}$ & $7 \cdot 39 \star \star$ & $26(19)$ & $41(10)$ \\
\hline Cobalt-60 & 1.00 & 1.74 & $4 \cdot 36^{\star \star}$ & $7 \cdot 86^{\star \star}$ & $27(20)$ & $45(11)$ \\
\hline Zinc-65 & 0.80 & 1.86 & $6 \cdot 13^{\star \star}$ & $8 \cdot 39^{\star \star}$ & $27(20)$ & $43(11)$ \\
\hline Strontium-90 & 0.66 & $2 \cdot 20$ & 1.57 & 3.76 & $34(25)$ & $65(16)$ \\
\hline Zirconium-95 & 1.56 & 1.37 & $4 \cdot 14$ & $3 \cdot 38$ & $9(7)$ & $18(4)$ \\
\hline Iodine-131 & 1.66 & 1.92 & 2.02 & $3.99^{\star}$ & $16(12)$ & $31(8)$ \\
\hline Caesium-137 & 0.73 & $2 \cdot 11^{\star}$ & 1.77 & $4 \cdot 32^{\star}$ & $34(25)$ & $65(16)$ \\
\hline Polonium-210 & 1.63 & & 2.09 & $3 \cdot 26$ & $8(6)$ & $13(3)$ \\
\hline Uranium-233 & $1 \cdot 21$ & 1.57 & 1.06 & 0.63 & $11(8)$ & $25(6)$ \\
\hline Natural uranium & 0.78 & 1.50 & 0.84 & 0.02 & $18(13)$ & $47(12)$ \\
\hline Plutonium-239 & 0.57 & 0.50 & 1.70 & 0.74 & $13(10)$ & $27(7)$ \\
\hline Plutonium-241 & 0.96 & 1.50 & $7 \cdot 55$ & $2 \cdot 45$ & $9(7)$ & $15(4)$ \\
\hline Americium-241 & 0.82 & 1.87 & $7 \cdot 71$ & $3 \cdot 22$ & $12(9)$ & $18(4)$ \\
\hline
\end{tabular}

${ }^{\star} \mathrm{p}<0.05,{ }^{\star \star} \mathrm{p}<0.01$

tRelative to never having worked in a place potentially contaminated with that radionuclide, calculated with informative matched sets only. Subjects who had worked in different places were classified according to highest level
of potential contamination. ionising radiation. All those who had been monitored for radiation exposure had records of exposure to external sources of radiation from film badges or other dosimeters. Monitoring for internal contamination by radionuclides has varied over time and differed between establishments (table II). At Harwell radionuclides tended to be detected by non-specific urine analysis for gross $\alpha, \beta$, or $\gamma$ activity whereas at Winfrith they tended to be detected by whole body monitoring from the late 1960s. Documented evidence of internal contamination by at least one radionuclide or gross $\alpha$, $\beta$, or $\gamma$ activity in the urine was found in $25(18 \%)$ of the cases and $53(13 \%)$ of the controls (relative risk 1.64 ( $95 \%$ confidence interval 0.87 to 3.06$)$ ). Overall, there were no large differences between cases and controls in contamination assessed by gross $\alpha, \beta$, or $\gamma$ activity in the urine: evidence of contamination was found by $\alpha$ counting in six $(4 \%)$ of the cases and $10(2 \%)$ of the controls (relative risk $2.00(0.54$ to $7 \cdot 17)$ ), by $\beta$ counting in six (4\%) of the cases and $16(4 \%)$ of the controls (relative risk $1 \cdot 11(0.34$ to $3 \cdot 22)$ ), and by $\gamma$ counting in none of the cases and two $(0.5 \%)$ of the controls (relative risk $=0(0$ to $15 \cdot 97)$ ).

Twenty nine specific radionuclides were each detected at least once among the subjects, and table III shows those most commonly found. Many workers, especially those from Winfrith, had more than one radionuclide detected: the mean (SD) number of radionuclides detected in each worker with at least one radionuclide detected was $5 \cdot 7$ (3.04) for the cases and $2 \cdot 8(2.35)$ for the controls from Winfrith and $1.5(1.04)$ for the cases and $1.8(1.46)$ for the controls from the other establishments. The risk of prostatic cancer increased with increasing numbers of different specific radionuclides ever detected in the same person $\left(\chi^{2}\right.$ test for trend, $\chi^{2}=4.34, p=0.04$, data not shown). The trend was largely accounted for by Winfrith workers $\left(\chi^{2}=5.04, p=0.03\right)$ and by men who were aged under 75 at the time of registration or death from prostatic cancer $\chi^{2}=4 \cdot 26, p=0 \cdot 04$ ).

Table III shows that five radionuclides (tritium, iron-59, cobalt-60, caesium-134, and caesium-137) were detected significantly more often in the men with prostatic cancer than in the controls. Contamination with ${ }^{3} \mathrm{H}$ was significantly associated with an increased risk of prostatic cancer at Winfrith (six cases $(21 \%) v$ one control $(1 \%)$; relative risk $\infty$ (95\% confidence interval 3.07 to $\infty)$ ) and at other establishments (six cases $(6 \%) v$ five controls $(2 \%)$; relative risk $6.41(1.08$ to $67 \cdot 27)$ ). Ten men with prostatic cancer had evidence of contamination by ${ }^{59} \mathrm{Fe},{ }^{60} \mathrm{Co},{ }^{134} \mathrm{Cs}$, or ${ }^{137} \mathrm{Cs}$; nine were from Winfrith. Contamination by each of those four radionuclides was significantly associated with prostatic cancer in Winfrith employees alone. Among those who had ever been contaminated with a specific nuclide, the number of different occasions when the radionuclide was detected tended to be higher in the cases than the controls (thus for ${ }^{3} \mathrm{H}$ the median (range) number of occasions was 35 (1-191) for cases $v 3$ (1-130) for controls). When the analysis was restricted to cancers that had not been included in the first report of mortality in this workforce ${ }^{1}$ seven cases $(17 \%)$ and four controls $(1 \%)$ had evidence of contamination by ${ }^{3} \mathrm{H}$ (relative risk $8.71(1.61$ to 87.52$)$ ), and the relative risks for ${ }^{59} \mathrm{Fe}$, ${ }^{60} \mathrm{Co},{ }^{134} \mathrm{Cs}$, and ${ }^{137} \mathrm{Cs}$ ranged from $2 \cdot 26$ to 3.00 but their confidence intervals all contained one.

Table IV shows the potential exposure of the subjects to 15 radionuclides at work. Risk of prostatic cancer increased significantly with increasing level of potential exposure to seven of the 15 radionuclides $\left({ }^{3} \mathrm{H}\right.$, ${ }^{59} \mathrm{Fe},{ }^{60} \mathrm{Co}$, ${ }^{137} \mathrm{Cs}$, ${ }^{131} \mathrm{I}$, chromium-51, and zinc-65). In addition, the risk was significantly increased when potential exposure to five radionuclides $\left({ }^{3} \mathrm{H},{ }^{51} \mathrm{Cr},{ }^{59} \mathrm{Fe}\right.$, ${ }^{60} \mathrm{Co}$, and ${ }^{65} \mathrm{Zn}$ ) was probable and at a high level. Prostatic cancer risk increased significantly with in- 
creasing duration of work in buildings likely to be contaminated (at any level or at high level alone) for the same five radionuclides (table V). In general, the same radionuclides tended to be associated with risk of prostatic cancer on the basis of environmental assessments (tables IV and V) and internal monitoring data (table III). The associations were especially consistent and strong for ${ }^{3} \mathrm{H},{ }^{51} \mathrm{Cr},{ }^{59} \mathrm{Fe},{ }^{60} \mathrm{Co}$, and ${ }^{65} \mathrm{Zn}$, and table VI shows the relation between risk of prostatic cancer and exposure to each of these five radionuclides in various subgroups of the subjects. For each radionuclide the relative risks tended to be higher in younger men (aged $<75$ ), in men for whom prostatic cancer was given as the underlying cause of death, in men from Winfrith, and in men who began working in potentially contaminated workplaces in 1960-4. More subjects had worked in environments potentially contaminated by each radionuclide than had documented internal contamination with that radionuclide, and when those with known internal contamination were excluded from the calculations relative risk remained significant for each radionuclide except ${ }^{3} \mathrm{H}$ (table VI).

No substance or exposure studied other than the radionuclides already mentioned was consistently associated with a significantly increased risk of prostatic cancer. In particular, risk of prostatic cancer was not associated with contamination with isotopes of plutonium or uranium (table III), working in environments potentially contaminated with those radionuclides (tables IV and V), or exposure at work to various metals, chemicals, physical agents, and other

TABLE V-Risk of prostatic cancer associated with duration of work in places assessed to be probably contaminated with 15 specific certain radionuclides among subjects employed by the United Kingdom Atomic Energy Authority

\begin{tabular}{|c|c|c|c|c|}
\hline \multirow[b]{2}{*}{ Radionuclide } & \multicolumn{2}{|c|}{ Relative risk by duration of work $\dagger$} & \multicolumn{2}{|c|}{$\begin{array}{l}\chi^{2} \text { Test for trend by level of } \\
\text { probable contamination }\end{array}$} \\
\hline & $<5$ Years & $\geqslant 5$ Years & $\begin{array}{l}\text { Low or high } \\
\quad \text { level }\end{array}$ & $\begin{array}{l}\text { High level } \\
\text { only }\end{array}$ \\
\hline Tritium & $1 \cdot 15$ & $6 \cdot 33^{\star \star}$ & $8 \cdot 72^{\star \star}$ & $9 \cdot 10^{\star \star}$ \\
\hline Chromium-51 & 1.96 & $2 \cdot 99^{\star \star}$ & $8 \cdot 66^{\star \star}$ & $12 \cdot 44^{\star \star}$ \\
\hline Iron-59 & 2.09 & $3.03^{\star \star}$ & $9 \cdot 01^{\star \star}$ & $10 \cdot 71^{\star \star}$ \\
\hline Cobalt- 60 & 1.89 & $2 \cdot 78^{\star}$ & $7 \cdot 94^{\star \star}$ & $9 \cdot 01^{\star \star}$ \\
\hline Zinc-65 & 2.02 & $3 \cdot 01^{\star \star}$ & $9 \cdot 10^{\star \star}$ & $10.71^{\star \star}$ \\
\hline Strontium-90 & 1.76 & $2 \cdot 35^{\star}$ & $6 \cdot 78^{\star \star}$ & 0.41 \\
\hline Zirconium-95 & $1 \cdot 37$ & 1.69 & $1 \cdot 10$ & 2.00 \\
\hline Iodine-131 & 1.92 & 1.65 & 1.94 & $1 \cdot 24$ \\
\hline Caesium-137 & 1.76 & $2 \cdot 35^{\star}$ & $6 \cdot 78^{\star \star}$ & 0.93 \\
\hline Polonium-210 & $2 \cdot 46$ & 1.90 & 1.72 & $1 \cdot 72$ \\
\hline Uranium-233 & $1 \cdot 10$ & 1.60 & 0.92 & 0.02 \\
\hline Natural uranium & 1.09 & $1 \cdot 34$ & 0.44 & 0.35 \\
\hline Plutonium-239 & 0.78 & $2 \cdot 17$ & $2 \cdot 29$ & $3 \cdot 20$ \\
\hline Plutonium-241 & $1 \cdot 42$ & $2 \cdot 42$ & $2 \cdot 45$ & $2 \cdot 60$ \\
\hline Americium-241 & 1.51 & $2.75^{\star}$ & $4 \cdot 37^{\star}$ & $2 \cdot 60$ \\
\hline
\end{tabular}

${ }^{\star} \mathrm{p}<0.05,{ }^{\star \star} \mathrm{p}<0.01$.

tRelative to never having worked in a place potentially contaminated with that radionuclide, calculated with informative matched sets only.

TABLE VI-Relative risk* ( $p$ value) of prostatic cancer associated with working in places assessed to be probably contaminated with five radionuclides among subjects employed by the United Kingdom Atomic Energy Authority

\begin{tabular}{|c|c|c|c|c|c|}
\hline & \multicolumn{5}{|c|}{ Radionuclide } \\
\hline & Tritium & Chromium-51 & Iron-59 & Cobalt -60 & Zinc-65 \\
\hline All subjects & $2.47(0.02)$ & $2.64(0.01)$ & $2.58(0.01)$ & $2.98(0.001)$ & $2.26(0.01)$ \\
\hline \multicolumn{6}{|c|}{ Age at diagnosis of cancer or death (years): } \\
\hline$<75$ & $6.34(<0.001)$ & $3.33(0.01)$ & $3.08(0.01)$ & $5.98(<0.001)$ & $2.62(0.03)$ \\
\hline$\geqslant 75$ & $0.45(0.50)$ & $1.95(0.28)$ & $2.00(0.26)$ & $1.53(0.52)$ & $1.82(0.33)$ \\
\hline \multicolumn{6}{|l|}{ Classification of prostatic cancer: } \\
\hline As underlying cause of death & $3.25(0.04)$ & $3.46(0.01)$ & $3.36(0.01)$ & $5.08(0.002)$ & $2 \cdot 70(0.04)$ \\
\hline As associated cause of death & $0.69(1.00)$ & $1.69(0.78)$ & $1.59(0.84)$ & $2.05(0.53)$ & $2 \cdot 16(0 \cdot 49)$ \\
\hline Diagnosed & $2 \cdot 83(0 \cdot 18)$ & $2 \cdot 22(0 \cdot 27)$ & $2 \cdot 20(0.25)$ & $1.95(0.35)$ & $1.79(0.41)$ \\
\hline \multicolumn{6}{|l|}{ Place of work: } \\
\hline Winfrith & $4.57(0.05)$ & $4.07(0.07)$ & $4.07(0.07)$ & $4.07(0.07)$ & $4.07(0.07)$ \\
\hline \multirow{2}{*}{\multicolumn{6}{|c|}{ Year of first work in potentially contaminated workplace: }} \\
\hline & & & & & \\
\hline Before 1960 & $1.48(0.49)$ & $2 \cdot 16(0.05)$ & $2.31(0.04)$ & $1.92(0.09)$ & $2.13(0.05)$ \\
\hline $1960-64$ & $2.87(0.07)$ & $6.59(0.003)$ & $6.73(0.003)$ & $4.03(0.02)$ & $5 \cdot 14(0.01)$ \\
\hline $1965-69$ & $2 \cdot 18(0 \cdot 17)$ & $1.50(0.52)$ & $1.50(0.51)$ & $1.58(0.47)$ & $1.49(0.52)$ \\
\hline After 1969 & $2.89(0.30)$ & $2.93(0.31)$ & $2.97(0.30)$ & $4.44(0.11)$ & $4.52(0.11)$ \\
\hline \multirow{2}{*}{$\begin{array}{l}\text { After excluding men known to be } \\
\text { contaminated }\end{array}$} & & & & & \\
\hline & $1.06(1.00)$ & $2.68(0.004)$ & $2.22(0.03)$ & $2.32(0.03)$ & $2.08(0.03)$ \\
\hline
\end{tabular}

* Relative to never having worked in a place potentially contaminated with relevant radionuclide, calculated with informative matched sets only.
TABLE VII-Risk of prostatic cancer associated with working in places assessed to be potentially contaminated with various substances or radiation among men with prostatic cancer (cases) and controls employed by the United Kingdom Atomic Energy Authority

\begin{tabular}{|c|c|c|c|}
\hline & \multicolumn{2}{|c|}{$\begin{array}{l}\text { No (\%) of subjects exposed } \\
\text { to potential contamination }\end{array}$} & \multirow[b]{2}{*}{$\begin{array}{l}\text { Relative risk }(95 \% \\
\text { confidence interval }\end{array}$} \\
\hline & $\begin{array}{c}\text { Cases } \\
(n=136)\end{array}$ & $\begin{array}{l}\text { Controls } \\
(n=404)\end{array}$ & \\
\hline \multicolumn{4}{|c|}{ Metals } \\
\hline Beryllium & $7(5)$ & $23(6)$ & $0.87(0.30$ to 2.17$)$ \\
\hline Boron & $8(6)$ & $10(2)$ & $2.67(0.90$ to 7.79$)$ \\
\hline Cadmium & $12(9)$ & $35(9)$ & $1.06(0.46$ to 2.30$)$ \\
\hline Lead & $31(23)$ & $82(20)$ & $1.21(0.69$ to 2.10$)$ \\
\hline Mercury & $13(10)$ & $37(9)$ & $1.00(0.47$ to 1.99$)$ \\
\hline Zinc & $6(4)$ & $28(7)$ & $0.61(0.19$ to 1.62$)$ \\
\hline \multicolumn{4}{|c|}{ Chemicals } \\
\hline Aromatic & $33(24)$ & $106(26)$ & $0.87(0.50$ to 1.48$)$ \\
\hline Halo & $60(44)$ & $171(42)$ & $1.10(0.68$ to 1.79$)$ \\
\hline Other organic & $56(41)$ & $178(44)$ & $0.89(0.55$ to 1.46$)$ \\
\hline \multicolumn{4}{|c|}{ Physical agents } \\
\hline Asbestos & $37(27)$ & $100(25)$ & $1.15(0.65$ to 2.05$)$ \\
\hline Metal dusts & $32(24)$ & $83(21)$ & $1.30(0.76$ to 2.22$)$ \\
\hline Metal fumes & $12(9)$ & $23(6)$ & $1.64(0.71$ to 3.62$)$ \\
\hline \multicolumn{4}{|c|}{ Radiation } \\
\hline Non-ionizing & $4(3)$ & $17(4)$ & $0.66(0.16$ to 2.12$)$ \\
\hline High energy $\gamma$ & $18(13)$ & $42(10)$ & $1.50(0.64$ to 3.46$)$ \\
\hline Neutrons & $30(22)$ & $73(18)$ & $1.52(0.76$ to 3.07$)$ \\
\hline Charged particles & 0 & $6(1)$ & $0.00(0$ to 2.55$)$ \\
\hline $\begin{array}{l}\text { High linear energy transfer } \\
\text { radiation }\end{array}$ & $30(22)$ & $86(21)$ & $1.03(0.57$ to 1.87$)$ \\
\hline Low linear energy transfer & & $00(21)$ & $105(0.3101 .01)$ \\
\hline radiat & $43(32)$ & $117(29)$ & $1.23(0.64$ to 2.37$)$ \\
\hline$x$ Irradiation & $6(4)$ & $23(6)$ & $0.76(0.22$ to 2.23$)$ \\
\hline
\end{tabular}

^Relative to never having worked in a place potentially contaminated with relevant substance or radiation, calculated with informative matched sets only.

types of radiation including non-ionising radiation (table VII).

Examination of the workplace suggested that an increased risk of prostatic cancer was associated with working in reactor environments but not with working with radioactive fuel (table VIII). Working in the proximity of heavy water reactors was most strongly associated with risk of prostatic cancer (table IX). Risk of prostatic cancer increased with increasing duration of work in a heavy water reactor environment, and risk increased eightfold after subjects had worked in such an environment for 10 years or longer. Among those who had worked in heavy water reactor environments, the job descriptions of the 19 men with prostatic cancer did not differ from those of the controls (six had been mechanics, four engineers, four health physicists, two electricians, and three had held assorted jobs). Examination of 125 separate workplaces where radionuclide exposure might have occurred identified only one place that was significantly associated with an increased risk of prostatic cancer: the steam generating heavy water reactor at Winfrith, where nine of the men with prostatic cancer and nine controls had worked (relative risk $5.9(1.4$ to $35 \cdot 2))$. Working in that building for more than 10 years was associated with a relative risk of $8.0(1.9$ to 33.5$)$.

Because multiple exposures were common in individual subjects it was not possible to disentangle the independent effects of ${ }^{3} \mathrm{H},{ }^{51} \mathrm{Cr},{ }^{59} \mathrm{Fe},{ }^{60} \mathrm{Co}$, and ${ }^{65} \mathrm{Zn}$. Table $\mathrm{X}$ shows that, of the 14 cases with documented contamination by at least one of these radionuclides, six were contaminated with more than one radionuclide. All six were from Winfrith. Seven of the other men had contamination only by ${ }^{3} \mathrm{H}$ documented: all were from Harwell or Dounreay and all were classified as having worked in an environment with probable exposure to all five of the radionuclides of interest. The men with documented or likely contamination by the five radionuclides also had high exposures to external sources of radiation. The figure shows that among the controls the proportion with documented or likely 
TABLE VUI-Risk of prostatic cancer associated with various work environments where exposure to radionuclides may have occurred among men with prostatic cancer (cases) and controls employed by the United Kingdom Atomic Energy Authority

\begin{tabular}{|c|c|c|c|}
\hline & \multicolumn{2}{|c|}{$\begin{array}{l}\text { No (\%) of subjects who } \\
\text { ever worked in each } \\
\text { environment } \neq\end{array}$} & \multirow[b]{2}{*}{$\begin{array}{c}\text { Relative risk ( } 95 \% \\
\text { confidence interval) } \dagger\end{array}$} \\
\hline & $\begin{array}{c}\text { Cases } \\
(n=136)\end{array}$ & $\begin{array}{l}\text { Controls } \\
(n=404)\end{array}$ & \\
\hline Reactor & $29(21)$ & $56(14)$ & $2.03(1.08 \text { to } 3.84)^{\star}$ \\
\hline Reactor maintenance & $5(4)$ & $10(2)$ & $1.56(0.38$ to 5.92$)$ \\
\hline Radiochemical laboratory & $24(18)$ & $58(14)$ & $1.36(0.72$ to 2.54$)$ \\
\hline \multicolumn{4}{|l|}{ Fuel examination after } \\
\hline irradiation & $5(4)$ & $14(3)$ & $1.07(0.30$ to 3.24$)$ \\
\hline Fuel fabrication & $5(4)$ & $17(4)$ & $0.86(0.23$ to 2.80$)$ \\
\hline \multicolumn{4}{|l|}{ Decontamination, waste } \\
\hline disposal, laundry & $7(5)$ & $25(6)$ & $0.80(0.28$ to 2.01$)$ \\
\hline Fuel reprocessing & $1(1)$ & $6(1)$ & $0.50(0.01$ to 4.12$)$ \\
\hline
\end{tabular}

TABLE IX-Risk of prostatic cancer associated with duration of work in reactor environments among men with prostatic cancer (cases) and controls employed by the United Kingdom Atomic Energy Authority

\begin{tabular}{|c|c|c|c|c|}
\hline \multirow[b]{2}{*}{ Type of reactor } & \multicolumn{2}{|c|}{$\begin{array}{c}\text { No (\%) of subjects who ever worked in } \\
\text { each environment }\end{array}$} & \multirow[b]{2}{*}{$\begin{array}{l}\text { Relative risk }(95 \% \\
\text { confidence interval) } \dagger\end{array}$} & \multirow[b]{2}{*}{$\begin{array}{l}\chi^{2} \text { Test for } \\
\text { trend }\end{array}$} \\
\hline & $\begin{array}{c}\text { Cases } \\
(n=136)\end{array}$ & $\begin{array}{l}\text { Controls } \\
(n=404)\end{array}$ & & \\
\hline Heavy water: & $19(14)$ & $32(8)$ & $2.13(1.00 \text { to } 4.52)^{\star}$ & \\
\hline For $<5$ years & $8(6)$ & $20(5)$ & $1.47(0.62$ to 3.49$)$ & \\
\hline For $5-9$ years & $3(2)$ & $7(2)$ & $2.34(0.47$ to 11.59$)$ & $\begin{array}{c}8.94 \\
(n-0.003)\end{array}$ \\
\hline For $\geqslant 10$ years & $8(6)$ & $5(1)$ & $7.97(1.89 \text { to } 33.54)^{\star \star}$ & \\
\hline Others: & $10(7)$ & $24(6)$ & $1.72(0.59$ to 4.94$)$ & \\
\hline For $<5$ years & $7(5)$ & $12(3)$ & $2.32(0.73$ to 7.38$)$ & \\
\hline For 5-9 years & $2(1)$ & $6(1)$ & $1.24(0.24$ to 6.49$)$ & $\begin{array}{c}0.20 \\
(n=0.66)\end{array}$ \\
\hline For $\geqslant 10$ years & $1(1)$ & $6(1)$ & $0.82(0.08$ to 8.92$)$ & \\
\hline
\end{tabular}

${ }^{\star} \mathrm{p}<0.05,{ }^{\star \star} \mathrm{p}<0.01$

tRelative to never having worked in that environment, calculated with informative matched sets only

\pm Excluding 7 cases and 18 controls who also worked in heavy water reactors.

TABLE X-Details of 14 men with prostatic cancer employed by the United Kingdom Atomic Energy Authority who had documented internal contamination with at least one of five radionuclides

\begin{tabular}{|c|c|c|c|c|c|c|}
\hline \multirow{2}{*}{$\begin{array}{l}\text { Age at } \\
\text { death }\end{array}$} & \multicolumn{5}{|c|}{$\begin{array}{l}\text { Documented internal contamination (level of probable contamination of } \\
\text { workplace) with each radionuclide }\end{array}$} & \multirow{2}{*}{$\begin{array}{l}\text { Cumulative whole } \\
\text { body exposure } \\
\text { to external } \\
\text { radiation (mSv) }\end{array}$} \\
\hline & Tritium & Chromium-51 & Iron-59 & Cobalt -60 & Zinc-65 & \\
\hline \multicolumn{7}{|c|}{ Worked at Winifrith } \\
\hline 57 & No (high) & No (high) & No (high) & Yes (high) & No (high) & 15 \\
\hline 58 & Yes (high) & No (high) & Yes (high) & Yes (high) & No (high) & 113 \\
\hline 58 & Yes (high) & No (high) & No (high) - & Yes (high) & No (high) & 271 \\
\hline $66^{\star}$ & Yes (high) & No (high) & No (high) & Yes (high) & No (high) & 42 \\
\hline $66^{\star}$ & No (none) & No (none) & No (none) & Yes (none) & No (none) & 125 \\
\hline $66^{\star}$ & Yes (high) & No (high) & Yes (high) & Yes (high) & Yes (high) & 403 \\
\hline 68 & Yes (high) & No (high) & Yes (high) & Yes (high) & No (high) & 107 \\
\hline 69 & Yes (high) & No (high) & Yes (high) & Yes (high) & Yes (high) & 298 \\
\hline \multicolumn{7}{|c|}{ Worked at Harwell } \\
\hline 49 & Yes (high) & No (low) & No (low) & No (low) & No (low) & 220 \\
\hline 53 & Yes (high) & No (low) & No (low) & No (low) & No (low) & 48 \\
\hline $54^{\star}$ & Yes (high) & No (low) & No (low) & No (low) & No (low) & 116 \\
\hline $70^{\star}$ & Yes (high) & No (low) & No (low) & No (low) & No (low) & 307 \\
\hline $74^{\star}$ & Yes (high) & No (low) & No (low) & No (low) & No (low) & 54 \\
\hline \multicolumn{7}{|c|}{ Worked at Dounreay } \\
\hline 73 & Yes (high) & No (low) & No (low) & No (low) & No (low) & 158 \\
\hline
\end{tabular}

*Age at diagnosis of prostatic cancer.

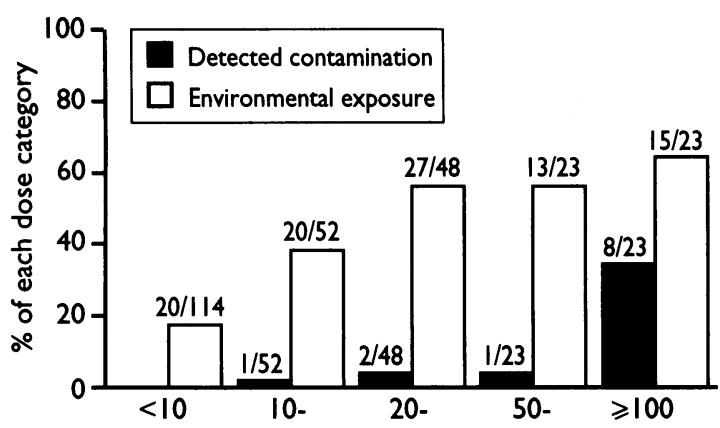

Cumulative external whole body exposure (mSv)

Percentages of 260 controls employed as radiation workers by United Kingdom Atomic Energy Authority who had documented internal contamination or worked in places potentially contaminated with at least one of five radionuclides (tritium, chromium-51, iron-59, cobalt-60, and zinc-65) by whole body exposure to external radiation environmental contamination by ${ }^{3} \mathrm{H},{ }^{51} \mathrm{Cr},{ }^{50} \mathrm{Fe},{ }^{60} \mathrm{Co}$, or ${ }^{65} \mathrm{Zn}$ increased as the cumulative whole body exposure to external radiation increased. Although there was a strong increase in risk of prostatic cancer with increasing dose of external radiation $\left(\chi^{2}\right.$ for trend $=7 \cdot 13, p=0.01$ ), the trend was evident only in the men who worked in areas where the five radionuclides of interest were likely to be found (table XI).

\section{Discussion}

The main result of this study is that the risk of prostatic cancer was increased in workers who were exposed to a group of radionuclides $\left({ }^{3} \mathrm{H},{ }^{51} \mathrm{Cr},{ }^{59} \mathrm{Fe}\right.$, ${ }^{60} \mathrm{Co}$, and ${ }^{65} \mathrm{Zn}$ ) which tend to be found together in the environment of certain reactors of the United Kingdom Atomic Energy Authority. Altogether 14 $(10 \%)$ of the 136 men with prostatic cancer and $12(3 \%)$ of the 404 controls were known to have been contaminated internally by one or more of these five radionuclides (relative risk $5.32(1.87$ to 17.24$)$ ). Twenty eight $(21 \%)$ men with prostatic cancer and 46 (11\%) controls had worked in environments that were potentially contaminated with one or more of them (relative risk $2.36(1.26$ to 4.43$)$ ), and about two thirds of these men worked at heavy water reactors (19 cases and 32 controls; relative risk $2.13(1.00$ to 4.52$))$. The relative risks increased with increasing level and duration of potential exposure to each radionuclide at work. The relative risks tended to be higher in younger men and in men whose deaths were directly attributed to prostatic cancer, suggesting that the malignancies associated with radionuclide exposure were not the relatively benign tumours sometimes diagnosed coincidentally in older men. Furthermore, when we excluded the 28 deaths from prostatic cancer that were initially described in this workforce ${ }^{1}$ there was still a significantly increased risk associated with internal contamination with one or more of the five radionuclides (relative risk 3.47 (1.07 to 12.15$)$ ), indicating that the findings reported here do not rely solely on the results reported previously.

The findings are coherent in that most of the significant results point to the same group of radionuclides irrespective of whether exposure was ascertained directly from evidence of individual contamination or indirectly on the basis of potential exposure in the workplace. Four of the five radionuclides $\left({ }^{51} \mathrm{Cr},{ }^{59} \mathrm{Fe},{ }^{60} \mathrm{Co}\right.$, and $\left.{ }^{65} \mathrm{Zn}\right)$ are produced by irradiation of the stainless steel casing and piping of certain reactors. They enter the environment mostly as oxides when the steel casing and piping age and corrode, usually in the form of small airborne particles (about $10 \mu \mathrm{m}$ in diameter) or in escaping steam. The fine particles may be inhaled or ingested by workers. The fifth radionuclide, ${ }^{3} \mathrm{H}$, is produced in the moderator fluid of heavy water reactors and enters the environment largely by evaporation and may be absorbed through the skin or inhaled by workers (United Kingdom Atomic Energy Authority, personal communication). Of the 28 men with prostatic cancer who had worked in environments potentially contaminated with at least one of these radionuclides, 19 had worked on heavy water reactors-and nine of these on the steam generating heavy water reactor at Winfrith (the largest heavy water reactor of the authority until it was shut in 1990). Mortality from prostatic cancer in 1946-86 was previously reported to be significantly above the national average in radiation workers from Winfrith (standardised mortality ratio 245) but not at Harwell, Culham, and London (standardised mortality ratio 69), or Dounreay (standardised mortality ratio 66 )..$^{5}$ Men who worked on the steam generating heavy water reactor at Winfrith had an increased risk of prostatic cancer, but this 
TABLE XI-Risk of prostatic cancer associated with cumulative whole body exposure to external radiation and environmental exposure to at least one of five radionuclides ${ }^{\star}$ among 88 men with prostatic cancer (cases) and 260 controls employed as radiation workers by the United Kingdom Atomic Energy Authority

Cumulative external

whole body exposure

$(\mathrm{mSv})$

No of cases

No of controls

Relative risk (95\%

confidence interval) $t$

$\chi^{2}$ Test for

Probable environmental exposure

$<10$
$10-$
$20-$
$50-$
$\geqslant 100$

5
5
9
8
14

1

$\begin{array}{ll}20 & 1 \\ 20 & 1.29(0.13 \text { to } 13 \cdot 10) \\ 27 & 2.03(0.34 \text { to } 12.04) \\ 13 & 1.96(0.33 \text { to } 11.52) \\ 15 & 4.79(0.85 \text { to } 26.93)\end{array}$

$<10$
$10-$
$20-$
$50-$
$\geqslant 100$

No environmental exposure

$\left.\begin{array}{rl}94 & 1 \\ 32 & 0.87(0.29 \text { to } 2.63) \\ 21 & 1.35(0.37 \text { to } 4.87) \\ 10 & 1.30(0.16 \text { to } 10.77) \\ 8 & 1.02(0.17 \text { to } 6.34)\end{array}\right\} \quad \begin{gathered}0.09 \\ (\mathrm{p}=0.77)\end{gathered}$

$<10$

$<10$
$10-$
$20-$
$50-$

$20-$
$50-$
$100-$

\section{All subjects}

$\left.\begin{array}{ll}\begin{array}{l}\text { All subjects } \\ 114\end{array} & 1 \\ 52 & 0.72(0.32 \text { to } 1 \cdot 61) \\ 48 & 1.38(0.61 \text { to } 3 \cdot 10) \\ 23 & 1.91(0.74 \text { to } 4.89) \\ 23 & 3.14(1.31 \text { to } 7.54)\end{array}\right\} \quad \begin{gathered}7 \cdot 13 \\ (\mathrm{p}=0.01)\end{gathered}$

*Tritium, chromium-51, iron-59, cobalt- 60 , and zinc- 65 . cobalt -60 , and zinc- 65 .
tRelative to $<10 \mathrm{mSv}$ external †Relative to $<10 \mathrm{mSv}$ exte
exposure, calculated with informative matched sets only.

risk was not significantly different from that associated with working on other reactors.

Risk of prostatic cancer was not found to be consistently associated with any other potentially hazardous occupational exposure in atomic energy authority establishments. There was no evidence of an increased risk in those subjects with documented contamination by or potential exposure to plutonium or uranium. Isolated significant results such as for ${ }^{131} \mathrm{I}$, ${ }^{134} \mathrm{Cs}$, ${ }^{137} \mathrm{Cs}$, americium-241, or strontium-90 might have been due to chance or arisen because these radionuclides tend to be found in association with the ones linked to prostatic cancer. There was also no evidence of an increased risk of prostatic cancer in subjects with likely environmental exposure to chemicals, physical agents, or non-radioactive metals such as cadmium, boron, or beryllium. These findings are in accord with results from other studies, which have failed to show consistent associations between risk of prostatic cancer and any specific occupation or exposure. $^{67}$

The cases and controls in this study were closely matched in their personal characteristics and employment history. All sociodemographic, occupational, and exposure details analysed were abstracted from the United Kingdom Atomic Energy Authority's records. These results could not have been influenced by the knowledge of who had prostatic cancer as the data were recorded before prostatic cancer developed and were assembled and classified for this study in ignorance of who had cancer.

The number of workers contaminated internally by

\section{Public health implications}

- Previous studies of employees of the United Kingdom Atomic Energy Authority who had accumulated high exposures from external radiation and who had been investigated for internal contamination with radionuclides showed increased mortality from prostatic cancer

- A detailed case-control study of contamination with specific radionuclides and other potentially hazardous exposures was made among these workers

- Increased risk of prostatic cancer was consistently associated with exposure to a group of radionuclides-tritium, chromium-51, iron-59, cobalt-60, and zinc-65-that tend to be found together in the environment of heavy water reactors

- Little is known about the uptake of these radionuclides and their radiobiological effects on the prostate

- Exposure to these radionuclides was uncommon and did not affect the overall health of the workforce the radionuclides identified here may be underestimated because whole body monitoring-which is used to detect ${ }^{51} \mathrm{Cr},{ }^{59} \mathrm{Fe},{ }^{60} \mathrm{Co}$, and ${ }^{65} \mathrm{Zn}$ - began only in the 1960 s and was generally limited to certain workers at Winfrith and Dounreay. Only eight $(6 \%)$ of the cases and seven $(2 \%)$ of the controls had recorded contamination whereas $27(20 \%)$ cases and $45(11 \%)$ controls had worked in places where contamination by at least one of the four radionuclides may have occurred. After men with known contamination had been excluded, the association between risk of prostatic cancer and potential contamination of the workplace by ${ }^{51} \mathrm{Cr},{ }^{59} \mathrm{Fe}$, ${ }^{60} \mathrm{Co}$, and ${ }^{65} \mathrm{Zn}$ remained significant.

Although these results identify a group of related radionuclides as putative carcinogens, they cannot show which of these radionuclides were responsible for the increased risk of prostatic cancer. Exposure to the five radionuclides tended to be simultaneous, and whole body monitoring may not be a sensitive way of detecting contamination by a radionuclide which is concentrated in and causes local damage to the prostate. Speculation about the possible role of the radionuclides identified here in prostatic cancer can therefore only be based on other knowledge. Elemental zinc has long been known to be concentrated in the prostate and seminal fluid. ${ }^{89}$ Uptake of ${ }^{65} \mathrm{Zn}$ is more than 20 times greater by the lateral lobe of the prostate than by muscle in rats, but there are no reliable data on ${ }^{65} \mathrm{Zn}$ uptake by the human prostate. ${ }^{10} \mathrm{Zinc}$ binds to nucleic acids, and $70 \%$ of the zinc contained in the prostate is located in the nuclei of prostatic acinar cells. ${ }^{11}$ Since $99 \%$ of the radioactive decays of ${ }^{65} \mathrm{Zn}$ lead to the emission of Auger electrons, which deliver their energy (albeit a small proportion of the total decay energy) over extremely short distances, ${ }^{12}{ }^{13}$ the selective concentration of ${ }^{65} \mathrm{Zn}$ in the nucleus of prostatic cells might result in biological effects greater than would be predicted by conventional dosimetric methods. No other radionuclide linked here with prostatic cancer is known to be concentrated in the prostate, but more needs to be known about the metabolism and radiobiological effects of ${ }^{3} \mathrm{H}$ and reactor activation products in general.

External ionising radiation was unlikely to have caused these cancers even though increasing levels of exposure to external radiation were associated with a significantly increased risk of prostatic cancer. Exposure to the radionuclides of interest and cumulative external dose were correlated, and the association between risk of prostatic cancer and external dose was limited to those subjects who were probably contaminated with the radionuclides. Furthermore, other populations exposed to high doses of external ionising radiation have no evidence of an increased risk of prostatic cancer. ${ }^{14}$

Studies of cancer in workers in the nuclear industry have tended to focus on its relation to the dose of external radiation, and most workforces have experienced a small and generally non-significant increase in overall mortality from prostatic cancer. ${ }^{15-21}$ The only other study which examined potential exposure to any of the radionuclides identified here found an increase in mortality from prostatic cancer in men who had been investigated for possible exposure to ${ }^{3} \mathrm{H}$ and who had received high doses of external radiation at the Atomic Weapons Establishment, Aldermaston. ${ }^{15}$ Workers from the Savannah River Plant in the United States, which contains five reactors and two heavy water manufacturing plants, did not experience an overall increase in prostatic cancer, but no separate data were given for employees exposed to specific radionuclides. ${ }^{21}$ There is a need for detailed analyses of risk of prostatic cancer in other workforces of the nuclear industry focused directly on people exposed to the radionuclides identified here. 
Although the present results indicate a possible occupational cause of prostatic cancer, this had little effect on the overall health of the atomic energy authority's workforce. Exposure to the radionuclides associated with prostatic cancer was uncommon: only $3 \%$ of the controls in this study had known contamination and $11 \%$ had worked in places where contamination might have occurred. Fourteen men with known contamination and 28 who had worked in places where contamination might have occurred developed prostatic cancer in the 41 years from 1946 to 1986. During the same period 5509 deaths were reported in the authority's cohort study, and the total death rate was $22 \%$ below the national average. ${ }^{5}$

The members of the Epidemiological Monitoring Unit were funded by the Medical Research Council through contracts held with the United Kingdom Atomic Energy Authority. We thank members of these organisations for their support and cooperation, in particular Len Salmon, Dallas Law, Jean Rose, medical staff, and health physicists for their help. We also thank Lucy Carpenter, David Dunn, Dudley Goodhead, Peter Smith, and Hazel Inskip for advice and Sarah Firsht, Anja Griffioen, Evangelia Tzala, and Craig Higgins for help with data processing.

1 Beral V, Inskip H, Fraser P, Booth M, Coleman D, Rose G. Mortality of employees of the United Kingdom Atomic Energy Authority, 1946-79. employees of the Un
$B M 71985 ; 291: 440-7$.

2 Fraser $P$, Booth $M$, Beral V, Inskip H, Firsht S, Speak S. Collection and validation of data in the United Kingdom Atomic Energy Authority mortality study. BMF 1985;291:435-9.

3 Breslow NE, Day NE. Statistical methods in cancer rearch. Vol 1. The analysis of case-control studies. Lyons: International Agency for Research on Cancer, 1980. (IARC scientific publications No 82.)

4 Epidemiological Resources Incorporated. EGRET: epidemiological graphics, estimation and testing. Seattle, Washington: Epidemiological Resources,
1990.

\section{Antibiotic induced fatigue}

\section{Jean-François Bergmann, Olivier Chassany, \\ Silla M Consoli, Evelyne Buteau, Hakim Bendjenana, Franck Le Mercier, Jean-Marc Segrestaa, Charles Caulin}

Therapeutics Research

Unit, Lariboisière Hospital, 75010 Paris Jean-François Bergmann, senior lecturer Evelyne Buteau, research fellow

Hakim Bendjenana, research fellow

Jean-Marc Segrestaa, professor

Charles Caulin, professor

\section{Department of}

Psychological Medicine, Broussais Hospital, 75014 Paris

Silla M Consoli, professor

Pharmacy, Lariboisière Hospital, 75010 Paris Franck Le Mercier, research fellow

Dr Bergmann.

$B M \Im$ 1993;307:1397-8
Olivier Chassany, lecturer

Correspondence to:
Antibiotics are prescribed for various reasons. ${ }^{1}$ Some patients demand antibiotic treatment for fatigue and others refuse such treatment because they believe it to be responsible for the onset of fatigue. It is reasonable to assume that fatigue is secondary to the initial illness rather than to the treatment itself. To check this hypothesis we compared placebo with amoxycillin in a double blind, randomised crossover trial in healthy volunteers. Our particular aim was to find out whether certain psychological characteristics are linked to side effects during clinical trials.

\section{Subjects, methods, and results}

Informed, healthy medical students or nurses volunteered for the study. A personality questionnaire including Bortner's rating scale ${ }^{2}$ and Levenson's locus of control scale ${ }^{3}$ was completed at the start of the trial. Bortner's scale ranges from 0 (extreme type A behaviour: competitive, impatient) to 24 (extreme type B behaviour: relaxed, easy going). Levenson's scale measures whether subjects consider themselves to be in control of life events (internal locus of control) or more dependent on outside factors (external locus of control). Subjects received in a randomised order amoxycillin $500 \mathrm{mg}$ thrice daily or placebo for one week, with a two week wash out period.

At the end of each treatment period the subjects were compared for the presence or absence of fatigue
5 Fraser P, Carpenter L, Maconochie N, Higgins C, Booth M, Beral V. Cancer mortality and morbidity in employees of the United Kingdom Atomic Energy Authority, 1946-86. Br f Cancer 1993;67:615-24.

6 Nomura A, Kolonel LN. Prostate cancer: a current perspective. Epidemiol Rev 1991;13:200-27.

7 Thun MJ, Schnorr TM, Smith AB, Halperin WE, Lemen RA. Mortality among a cohort of US cadmium production workers-an update. $f$ Natl Cancer Inst 1985;74:325-33.

8 Schroeder HA, Nason AP, Tipton IH, Balassa JJ. Essential trace metals in 1967;20:179-210.

9 Byar DP. Zinc in male sex accessory organs: distribution and hormonal Press, 1974:161-71.

10 Byar DP, Anderson JE, Mostofi FK. The distribution of "Sinc in the prostate and other organs in control, castrated, and hypophysectomized rats. Investigative Urology 1969;7:57-65.

11 Costello LC, Franklin RB. Concepts of citrate production and secretion by prostate. I. Metabolic relationships. Prostate 1991;18:25-46.

12 Martin MJ, Blichert-Toft PH. Radioactive atoms. Auger-electron, $\alpha-, \beta-, \gamma$ - and $x$-ray data. London: Academic Press, 1970.

13 Auger cascades and nuclear medicine. Lancet 1985;ii:533-4.

14 Shimizu Y, Kato H, Schull WJ, Preston DL, Fujita S, Pierce DA. Life span study report 11. Part 1. Comparison of risk coefficients for site-specific cancer mortality based on the DS86 and T65DR shielded Kerma and Organ doses. Hiroshima, Japan: Radiation Effects Research Foundation, 1987:1-56. (Radiation Effects Research Foundation technical report series No 12.)

15 Beral V, Fraser P, Carpenter L, Booth M, Brown A, Rose G. Mortality of employees of the Atomic Weapons Establishment, 1951-82. BMF 1988;297: $757-70$.

16 Smith PG, Douglas AJ. Mortality of workers at the Sellafield plant of British Nuclear Fuels. BMf 1986;293:845-54.

17 Gilbert ES, Marks S. An analysis of the mortality of workers in a nuclear facility. Radiat Res 1979;79:122-48.

18 Gilbert ES, Petersen GR, Buchanan JA. Mortality of workers at the Hanford site: 1945-1981. Health Phys 1989;56:11-25.

19 Wilkinson GS, Tietjen GL, Wiggs LD, Galke WA, Acquavella JF, Reyes M, et al. Mortality among plutonium and other radiation workers at a plutonium et al. Mortality among plutonium and other radiation

20 Wing S, Shy CM, Wood J,, Wolf S, Cragle DL, Frome EL. Mortality among

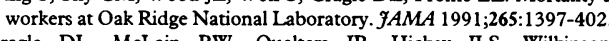

21 Cragle DL, McLain RW, Qualters JR, Hickey JLS, Wilkinson GS, Tankersley WG, et al. Mortality among workers at a nuclear fuels production facility. Am f Ind Med 1988;14:379-401.

(Accepted 23 August 1993) man: zinc. Relation to environmental cadmium. Foumal of Chronic Diseases response. In: Brandes D, ed. Male accessory sex organs. London: Academic

by using the $\chi^{2}$ test. Psychological profiles were compared with the sum of the fatigue scores recorded at the end of the two treatment periods (verbal score with six points from 0 to 5 ) by using the nonparametric Kruskal-Wallis test. We estimated that 80 subjects would be needed in a crossover design to obtain a sample with a $20 \%$ difference in incidence of fatigue ( $10 \%$ with placebo $v 30 \%$ with amoxycillin) at a risk of $\alpha=5 \%, \beta=10 \%$.

The study included 79 subjects (50 women); their mean (SD) age was $28.4(6.9)$ years. The only side effect noted was a mild generalised erythematous rash after the first day of the initial treatment (placebo); the subject withdrew from the study. On Bortner's scale four subjects were type $A, 38$ type $A B$, and 37 type $B$; on Levenson's scale 21 subjects had an internal locus of control, 27 a median locus, and 24 an external locus.

Six subjects recorded fatigue after amoxycillin and five after placebo $(p=0.76)$ with no period effect. Only one subject recorded fatigue during both treatment periods. The fatigue score at the end of the treatments was associated with type B behaviour $(p<0.05)$ and the external locus of control $(p<0.03)$. Medians and interquartile ranges for Bortner's scale were respectively 0 and 0 to 1 in type $A$ subjects, 1 and 0 to $2 \cdot 25$ in type $A B$ subjects, and 2 and 0 to 4 in type $B$ subjects (KruskalWallis test, $\mathrm{p}<0.05, \mathrm{~A}<\mathrm{B}$ ). For Levenson's scale medians and interquartile ranges were respectively 1 and 0 to 3 in those with an internal locus, 2 and 0 to 4 in those with a median locus, and 2 and 0 to 4 in those with an external locus (Kruskal-Wallis test, $p<0.03$, internal $<$ median, internal $<$ external).

\section{Comment}

Patients often believe antibiotics to be responsible for generalised fatigue. This widely held view has clearly been invalidated by this trial, which shows that 